\title{
BET Inhibitor GSK2820151
}

National Cancer Institute

\section{Source}

National Cancer Institute. BET Inhibitor GSK2820151. NCI Thesaurus. Code C125391.

An orally bioavailable inhibitor of the Bromodomain and Extra-Terminal (BET) family of proteins, with potential antineoplastic activity. Upon oral administration, the BET inhibitor GSK2820151 binds to the acetylated lysine recognition motifs in the bromodomains of BET proteins, thereby preventing the interaction between the BET proteins and acetylated histones. This disrupts chromatin remodeling and gene expression. Prevention of the expression of certain growth-promoting genes may lead to an inhibition of tumor cell growth. BET proteins, comprised of BRD2, BRD3, BRD4 and BRDT, are transcriptional regulators that play an important role during development and cellular growth. 